\title{
INVESTASI ETIS (KONSEP, DASAR PERTIMBANGAN DAN PENDEKATAN)
}

\author{
Abdulloh Mubarok \\ Mahasiswa Program Doktor Ilmu Ekonomi \\ Fakultas Bisnis dan Ekonomika Universitas Islam Indonesia \\ Mubarok31@gmail.com
}

\begin{abstract}
Ethical investment has experienced very fast and high growth over the last decade. The growth and development of this investment occurs both at the local (Indonesian) level and at the global level. In Indonesia, the growth and development of ethical investment can be seen from the increasing number of ethical-based stock indices and the value of stock market capitalization in each of these indices. Meanwhile at the global level, it can be seen from the increase in the value of ethical investments, especially in the five main world markets, namely Europe, the United States, Japan, Canada and Australia and New Zealand. Underlying this phenomenon needs to be explored further on the issue of ethical investment. This article tries to explore more deeply ethical investing, especially regarding the concepts, basis for decisions and approaches (strategies) in ethical investment activities.
\end{abstract}

Keywords Ethical Investment, Environment, Social, Governance, Screening, Shareholder Activism, Community Development Investing

\section{PENDAHULUAN}

Investasi etis mengalami pertumbuhan yang sangat cepat dan tinggi selama dekade terakhir ini (Renneboog, Ter Horst dan Zhang, 2008; Albaity dan Ahmad, 2011; Pena dan Cortez, 2017; Tseng, Tan, Jeng, Lin, Negash dan Darsono, 2019). Kegiatan investasi ini telah beralih dari yang sebelumnya marjinal menjadi mainstream (Louche dan Lydenberg, 2006; Pena dan Cortez, 2017). Pertumbuhan dan perkembangan investasi ini terjadi baik di tingkat lokal (Indonesia) maupun di tingkat global.

Di Indonesia, pertumbuhan dan perkembangan investasi etis tampak dari semakin bertambahnya jumlah indek saham berbasis etika dan nilai kapitalisasi pasar saham pada masing-masing indek tersebut. Terkait indek, sampai dengan akhir tahun 2019, ada 5 indeks yang dikategorikan sebagai indeks etis dari 34 indeks yang diterbitkan BEI. Indeks tersebut adalah Indek Bisnis-27 sebagai indek berbasis corporate governance $(C G)$, Indek Sri-Kehati sebagai indek berbasis sustenabilitas (Rafik dan Lantara, 2016), Jakarta Islamic Index (JII), Indeks Saham Syariah Indonesia (ISSI) dan Jakarta Islamic Index 70 (JII70), sebagai indek berbasis religius (syariah).

Adapun pertumbuhan nilai kapitalisasi pasar saham di masing-masing indek etis tersebut per-Desember 2019 tampak pada Table 1.1 di bawah ini.

Table 1 Nilai Kapitalisasi Pasar Saham Etis

\begin{tabular}{clc}
\hline No & \multicolumn{1}{c}{ Nama Indek Saham Etis } & Nilai Kapitalisasi Saham \\
\hline 1. & Bisnis-27 & Rp4.008,73 triliyun \\
2. & Sri-Kehati & Rp3.403,49 triliyun \\
3. & Jakarta Islamic Index (JII) & Rp2.318,57 triliyun
\end{tabular}


4. Indonesia Sharia Stock Index (ISSI)

5 Jakarta Islamic Index 70 (JII70)
Rp3.745,76 triliyun

Rp2.800,16 triliyun

Sumber: IDX Stock Index (2019)

Berdasarkan tabel tersebut tampak nilai kapitalisasi saham cukup besar meskipun bervariasi diantara masing-masing indek etis. Indek saham berbasis religius (syariah) tampak mendominasi. Lima kategori indek saham berbasis etika tersebut, tiga diantarannya merupakan indek saham berbasis syariah. Ketiga indek saham tersebut memiliki akumulasi nilai kapitalisasi pasar saham sebesar Rp8,864.49 triliyun atau mencapai $54,46 \%$ dari total nilai kapitalisasi pasar saham berbasis etika di Indonesia. Fenomena ini menunjukan tingginya investasi etis berbasis keyakinan mengikuti mayoritas penduduk Indonesia yang beragama Islam.

Di tingkat global, perkembangan investasi etis terlihat dari data aset investasi seperti yang dirilis The Global Sustainable Investment Alliance (GSIA), lembaga internasional di bidang investasi etis, pada tabel 1.2 di bawah ini.

Tabel 1.2 Aset Investasi Etis Global, 2016-2018

\begin{tabular}{lrrrr}
\hline Wilayah & \multicolumn{4}{c}{ Jumlah Aset } \\
\hline & & 2016 & & 2018 \\
Eropa & $\$$ & 12.040 & $\$$ & 14.075 \\
Amerika Serikat & $\$$ & 8.723 & $\$$ & 11.995 \\
Jepang & $\$$ & 474 & $\$$ & 2.180 \\
Kanada & $\$$ & 1.086 & $\$$ & 1.699 \\
Australia dan Selandia Baru & $\$$ & 516 & $\$$ & 734 \\
\hline \multicolumn{1}{c}{ Total } & $\$$ & $\mathbf{2 2 . 8 9 0}$ & $\$$ & $\mathbf{3 0 . 6 8 3}$ \\
\hline
\end{tabular}

Sumber: GSIA (2018)

Pada tabel tersebut tercatat pada 2016 nilai investasi etis global, khususnya di lima pasar utama dunia (Eropa, Amerika Serikat, Jepang, Kanada dan Australia dan Selandia Baru), mencapai $\$ 22,89$ triliun. Jumlah ini mengalami kenaikan menjadi $\$ 30,683$ triliun pada tahun 2018 atau naik sekitar 34,05\%. Secara umum tampak ada kenaikan aset investasi etis secara global dengan variasi pertumbuhan berbeda antara satu wilayah dengan wilayah lainnya (GSIA, 2018).

Artikel ini mencoba mengeksplorasi lebih mendalam tentang investasi etis, khususnya mengenai pengertian dan konsep investasi, berbagai kriteria atau dasar pertimbangan (obyek/dimensi) investasi etis dan berbagai pendekatan atau strategi investor dalam kegiatan investasi etis.

\section{LANDASAN TEORI}

Apa itu Investasi Etis?

Istilah investasi etis (ethical investment) bersinonim dengan istilah investasi tanggung jawab sosial (socially responsible investments/SRI) (Sandberg et al., 2009; Cowton, 2018). Michelson et al. (2004) menggunakan kedua istilah ini secara bergantian. Meskipun demikian, terminologi investasi etis dipandang sebagai terminologi tertua yang kemudian secara perlahan digantikan oleh terminologi investasi tanggung jawab sosial (Sparkes 2001). Istilah investasi etis lebih umum digunakan di Inggris sementara istilah investasi tanggung jawab sosial lebih banyak dipakai di Amerika Serikat (Reich et al., 2001; Michelson et al., 2004). 
Disamping investasi tanggung jawab secara sosial, istilah investasi etis dikenal juga dengan istilah lain seperti investasi berbasis nilai (values-based investing) (Schueth, 2003; Magnússon dan Dyremyhr, 2011; von Wallis dan Klein, 2015), investasi berkelanjutan (sustainable investment) (Forte dan Miglietta, 2011; Ortas dan Moneva, 2010), investasi tanggung jawab perusahaan (corporate responsible investments), investasi berbasis lingkungan, hijau, atau nilai (green, environmental or value based investing) (Magnússon dan Dyremyhr, 2011), investasi sosial (social investing) (Schueth, 2003; Sandberg et al., 2009), investasi sadar secara sosial (socially aware investing atau socially conscious investing), investasi berbasis misi (missionbased atau mission-related investing) (Schueth, 2003), investasi berbasis norma sosial (investing based on social norms) (Al-Awadhi, 2017), investasi bertanggung jawab (responsible investment), investasi berkelanjutan dan bertanggung jawab (sustainable and responsible investment), investasi bertanggung jawab secara sosial dan lingkungan (socially and environmentally responsible investment) dan investasi bertanggun jawab secara tata kelola dan sosial (governance and socially responsible investment) (Sandberg et al., 2009).

Meskipun begitu, beberapa akademisi memandang istilah investasi berbasis tanggung jawab sosial tidak mencakup aspek yang sama dengan istilah investasi etis Istilah investasi berbasis tanggung jawab sosial memiliki cakupan yang lebih sempit, yaitu hanya mencakup aspek sosial tidak termasuk aspek etis (Magnússon dan Dyremyhr, 2011). Sementara investasi etis, disamping mencakup aspek tanggung jawab sosial di atas juga mencakup aspek etis berbasis keyakinan agama (Mazouz, Mohamed dan Saadouni, 2016; Gillet dan Salaber-Ayton, 2017). Oleh karena itu istilah "investasi etis" lebih cocok dan kredibel bagi komunitas keuangan mainstream, termasuk investor institusi seperti lembaga dana pensiun dan reksadana, dibanding istilah investasi tanggung jawab sosial (Sandberg et al., 2009; Magnússon dan Dyremyhr, 2011).

Cowton (1994) mendefinisikan investasi etis sebagai investasi yang dalam seleksi dan pengelolaan portofolionya mendasarkan pada kriteria etis dan sosial. Di artikel lain Cowton (2018) mendefinisikannya (SRI) sebagai praktik integrasi pertimbangan sosial, lingkungan dan etika dalam keputusan investasi. Sementara Humphrey dan Lee (2011) mengartikannya sebagai pendekatan investasi yang mempertimbangkan etika, religius, sosial atau seleksi normatif lainnya dalam pengambilan keputusan investasi. Adapun Dunfee (2003) menjelaskan investasi etis (sosial) sebagai strategi investasi dengan menggunakan kriteria non-finansial. Contoh kriteria non-finansial menurut Dunfee antara lain kriteria sosial atau keagamaan. Sementara menurut Sandberg et al. (2009) meliputi etika, sosial, lingkungan dan corporate governance. Untuk kriteria sosial, Rockness dan Williams (1988) menjabarkan lebih lanjut yaitu meliputi perlindungan lingkungan, kesempatan kerja yang setara, perlakuan terhadap karyawan, hubungan dengan rezim represif, kualitas produk dan inovasi, dan kontrak defensif. Sandberg et al. (2009), setelah mengkaji berbagai istilah dan definisi investasi etis, menyimpulkan dengan menyatakan kebanyakan investor secara umum mendifinisikan praktik investasi etis (SRI) dengan menekankan pentingnya isu corporate governance, sosial dan lingkungan (ESG) dalam proses investasinya (analisis investasi atau seleksi portofolio). Mengacu definisi investasi etis menurut Dunfee (2003), Sandberg et al. (2009), Humphrey dan Lee (2011) dan Cowton (2018), investasi etis dapat diartikan sebagai investasi yang dalam keputusan pembentukan portofolio investasi mendasarkan integrasi beberapa kriteria non-finansial antara lain etika, sosial, lingkungan, governance dan religius. 
Akademisi lain mendefinisikan investasi etis dengan memasukan faktor ekonomi (keuangan). Michelson et al. (2004), misalnya, mengartikan investasi etis sebagai integrasi nilai personal, pertimbangan sosial dan faktor ekonomi dalam keputusan investasi. Return keuangan tetap penting meskipun bukan satu-satunya faktor yang menggerakan investasi. Cowton menjelaskan bahwa esensi investasi etis adalah menggunakan secara bersama nilai moral dan kriteria keuangan konvensional dalam keputusan membeli, mempertahankan dan menjual saham sebagai bagian dari portofolio investasi.

Terkait masuknya aspek keuangan dalam definisi investasi etis, Louche dan Lydenberg (2006) menemukan perbedaan definisi antara Amerika Serikat dan Eropa. Definisi investasi etis Amerika Serikat tidak memasukan aspek keuangan, sementara definisi Eropa menambahkan aspek keuangan. Definisi investasi etis Amerikas Serikat lebih digerakan nilai, sementara definisi investasi etis eropa lebih pragmatis, yaitu menekankan pentingnya kesamaan aspek sosial, lingkungan dan keuangan. Penekanan kesamaan tiga pilar ini dipengaruhi oleh konsep pembangunan berkelanjutan (the concept of sustainable development), sehingga investasi etis di Eropa dikenal juga dengan sustenabilitas atau a triple bottom line (planet, people dan profits) (Louche dan Lydenberg, 2006). Perbedaan definisi etis Amerika Serikat dan Eropa menggambarkan perbedaan budaya antara kedua masyarakat negara tersebut. Definisi investasi etis di Amerika Serikat didasarkan konfrontasi antara investor dan perusahaan, sementara definisi investasi etis di Eropa lebih didasarkan kerja sama dan persuasi (Sandberg et al., 2009).

Investasi etis secara umum dibagi dua jenis, yaitu investasi tanggung jawab sosial (socially responsible investment) dan investasi berbasis keyakinan (faith-based investment/fund) (Gillet dan Salaber-Ayton, 2017; Mazouz et al., 2016). Investasi tanggung jawab sosial mendasarkan keputusan investasinya pada faktor lingkungan, sosial dan governance, sementara investor etis berbasis keyakinan mendasarkan pada ajaran agama tertentu seperti agama Kristen dan Islam (Gillet dan Salaber-Ayton, 2017).

\section{Dasar (Kriteria) Pertimbangan Investasi Etis}

Mendasarkan definisi investasi etis sebagaimana dijelaskan para akademisi, terdapat beberapa dasar pertimbangan dalam pengambilan keputusan investasi etis. Dasar pertimbangan tersebut antara lain etika (Cowton, 1994, 2018; Sandberg et al., 2009; Humphrey dan Lee, 2011; Revelli dan Viviani, 2013) sosial (Rockness dan Williams, 1988; Cowton, 1994, 2018; Dunfee, 2003; Schueth, 2003; Michelson et al., 2004; Sandberg et al., 2009; Humphrey dan Lee, 2011; Revelli dan Viviani, 2013; Gillet dan Salaber-Ayton, 2017), lingkungan (Rockness dan Williams, 1988; Sandberg et al. 2009; Revelli dan Viviani, 2013; Gillet dan Salaber-Ayton, 2017; Cowton, 2018), corporate governance (CG) (Sandberg et al., 2009; Revelli dan Viviani, 2013), religius (Dunfee, 2003; Humphrey dan Lee, 2011; Gillet dan Salaber-Ayton, 2017), nilai-nilai personal (Schueth, 2003; Michelson et al., 2004) dan ekonomi (keuangan) (Michelson et al., 2004).

\section{Etika}

Kata "etika" berasal dari bahasa Yunani, yaitu "ethos", yang artinya karakter, sentimen, sifat moral, atau pedoman keyakinan individu, kelompok atau institusi. Nainawat dan Meena (2013: 1086) mengartikan etika sebagai "a set of principles or standards of human conduct that govern the behaviour of individuals or organization". 
Sementara Kamus Bahasa Indonesia (Balai Pustaka, 1999) mengartikan etika sebagai "nilai mengenai benar dan salah yang dianut satu golongan masyarakat tertentu" (Hanum, 2009). Adapun istilah "nilai" sendiri diartikan sebagai sesuatu yang abstrak, ideal, dan menyangkut persoalan keyakinan terhadap yang dikehendaki, dan memberikan corak pada pola pikiran, perasaan, dan perilaku (Djamal, 2018). Terkait investasi, etika merupakan salah satu dasar pertimbangan dalam pengambilan keputusan investasi etis. Artinya seorang investor memiliki prinsip atau keyakinan mengenai apa yang boleh (benar) dan yang tidak boleh (salah) dilakukan perusahaan, baik terkait cara ataupun sifat produk yang dihasilkan. Prinsip dan keyakinan tersebut nantinya digunakan sebagai dasar pertimbangan dalam memasukan perusahaan (saham) dalam portofolionya.

Dalam kegiatan investasi, terdapat kelompok investor tertentu, sebagai bagian masyarakat, yang meyakini beberapa perusahaan terlibat dalam pembuatan produk tidak etis (unethical products) (Salaber, 2013) atau memiliki perilaku yang dipermasalahkan secara etis (ethically questionable corporate behaviors) (Cahan et al., 2017). Perusahaan-perusahaan ini dikenal dengan istilah sin stocks (Salaber, 2013) atau sin industries (Cahan et al., 2017). Sin stocks dikenal juga dengan istilah "controversial stocks" (Nofsinger et al., 2016; Trinks dan Scholtens, 2017), "norm-conflicting stocks" (Al-awadhi dan Dempsey, 2017) atau "vice stocks" (Richey, 2017). Dalam masyarakat muslim, sin stocks dikenal dengan istilah saham non-syariah (non-Islamic stocks) (AlAwadhi, 2017).

Sin stocks merupakan saham dari perusahaan publik yang terlibat dalam pengolahan produk tidak etis (Salaber, 2013) atau saham dari perusahaan yang beroperasi pada industri yang dianggap berdosa (sin full) dari perspektif norma sosial tertentu (Al-awadhi dan Dempsey, 2017). Beberapa akademisi seperti Hong dan Kacperczyk (2009) dan Liston, (2016) mendefinisikan sin stocks dengan menyebutkan jenis industrinya, yaitu alcohol, tobacco dan gambling. Masyarakat barat mendefinisikan sin stocks mendasarkan pertimbangan norma sosial, sementara masyarakat Islam mendefinisikan sin stocks berdasarkan prinsip-prinsip agama Islam (Al-awadhi dan Dempsey, 2017).

Para akademisi berbeda dalam menentukan jumlah dan jenis saham yang masuk sin stocks. Leventis, Hasan dan Dedoulis (2013) dan Nofsinger et al. (2016), misalnya, membagi ke dalam enam jenis industri: alcohol, firearms, gambling, military, nuclear power, dan tobacco. Kim dan Venkatachalam (2011) membagi ke dalam lima jenis industri: alcohol, gambling, tobacco, sex dan adult entertainment industries. Hong dan Kacperczyk (2009), Hood, Nofsinger dan Varma (2014) dan Liston (2016) membagi ke dalam tiga jenis industri: alcohol, gambling (gaming), dan tobacco. Tiga jenis industri inilah yang sering digunakan akademisi untuk mendifinisikan sin stocks (Amory, 2016).

\section{Sosial dan lingkungan}

Dasar pertimbangan dalam keputusan investasi etis diantaranya adalah aspek sosial (Rockness dan Williams, 1988; Cowton, 1994, 2018; Dunfee, 2003; Schueth, 2003; Michelson et al., 2004; Sandberg et al., 2009; Humphrey dan Lee, 2011; Revelli dan Viviani, 2013; Gillet dan Salaber-Ayton, 2017) dan aspek lingkungan (Rockness dan Williams, 1988; Sandberg et al., 2009; Revelli dan Viviani, 2013; Gillet dan Salaber-Ayton, 2017; Cowton, 2018).

\section{a. Sosial}

Aspek sosial bersama aspek lingkungan dan $C G$ menjadi domain dalam pembahasan investasi etis (Nofsinger et al., 2016), khususnya jenis investasi etis berbasis tanggung jawab sosial (Gillet dan Salaber-Ayton, 2017). Aspek ini menjadi 
salah satu kriteria non-finansial yang diintegrasikan dalam proses investasi etis (Dunfee, 2003; Sandberg et al., 2009). Rockness dan Williams (1988) melakukan survey mengenai kriteria yang menjadi pertimbangan fund managers dalam pembentukan reksadana etis. Survey menemukan aspek sosial, khususnya isu kesetaraan dalam kesempatan kerja dan perlakuan terhadap karyawan, menjadi salah satu kriteria pembentukan portofolio reksadana.

Inderst dan Stewart (2018) menjelaskan isu utama yang menjadi pembahasan dalam aspek sosial antara lain pengembangan masyarakat, kebijakan tentang keragaman dan kesamaan dalam kesempatan kerja, hak asasi manusia, standar perburuhan, kesehatan dan keamanan, kebijakan keragaman, hubungan masyarakat dan pengembangan sumber daya manusia (kesehatan dan pendidikan). GAMCO (2016) meyebutkan enam isu sosial yaitu hak asasi manusia, keamanan produk, standar buruh, rantai pasokan, keamanan tenaga kerja dan keanekaragaman. Sementara Pena dan Cortez (2017), dalam menyusun tipe skrining berbasis sosial, memasukan beberapa isu seperti pengembangan masyarakat, keanekaragaman dan kebijakan kesempatan kerja yang setara, hak asasi manusia, hubungan perburuhan dan sudan (rejim opresif).

\section{b. Lingkungan}

Aspek lingkungan bersama aspek sosial dan CG menjadi domain dalam pembahasan investasi etis (Nofsinger et al., 2016), khususnya investasi etis berbasis tanggung jawab sosial (Gillet dan Salaber-Ayton, 2017). Aspek lingkungan juga menjadi salah satu kriteria pertimbangan fund managers dalam pembentukan reksadana etis (Rockness dan Williams, 1988). Unsur-unsur yang termasuk dalam kriteria lingkungan antara lain perubahan iklim, emisi karbon, polusi, efisiensi sumber, keanekaragaman hayati (penghijauan) (Inderst dan Stewart, 2018).

Beberapa perusahaan asset management juga mencontohkan unsur-unsur yang memerlukan perhatian di bidang lingkungan. GAMCO (2016), misalnya, menjelaskan enam unsur, yaitu polusi udara dan air, keanekaragaman hayati, jejak karbon, pengelolaan limbah, kelangkaan air dan penggunaan lahan. Adapun REBECO memasukan unsur keterlibatan perusahaan dan pemerintah dalam perubahan iklim melalui emisi gas rumah kaca, pengelolaan limbah, efisiensi energi, usaha kebaruan untuk mengurangi pemanasan global, emisi dan dekarbonisasi.

\section{c. Corporate Social Responsibility (CSR)}

Dalam pengujian aspek sosial dan lingkungan sebagai dasar pertimbangan keputusan investasi etis, peneliti kebanyakan menggunakan proksi variabel corporate social responsibility (CSR). Hal ini karena isu yang dibahas dalam CSR merupakan kombinasi isu sosial dan isu lingkungan. Saleh et al. (2010), misalnya, menganalisis disklosur CSR dengan empat dimensi, yaitu hubungan ketenagakerjaan, keterlibatan masyarakat, produk dan lingkungan. Cahan et al. (2017) menguji kinerja CSR dengan menganalisis enam area isu kualitatif CSR yang disusun KLD STATS, yaitu masyarakat, keanekaragaman (diversity), hubungan ketenagakerjaan, lingkungan, hak asasi manusia dan produk. Sementara Dyck et al. (2019) mengevaluasi CSR dengan menganalisis data kinerja sosial dan lingkungan dari the Thomson Reuters ASSET4 ESG database.

Definisi dan konsep CSR telah berkembang dari terbatas pada generasi keuntungan menjadi generasi nilai sustenabilitas (Agudelo et al., 2019). Konsep CSR terakhir ini, yaitu nilai sustenabilitas, terlihat dari definisi yang diberikan Chandler (2016). Chandler mendifinisikan (Strategic) CSR sebagai penggabungan perspektif CSR secara holistik dalam perencanaan strategis dan operasi inti perusahaan sehingga perusahaan dapat dikelola untuk kepentingan keseluruhan pemangku kepentingan guna 
mengoptimalkan nilai dalam jangka menengah sampai jangka panjang (Agudelo et al., 2019).

Definisi tersebut menjelaskan lima prinsip utama CSR: pertama, penggabungan perspektif $C S R$ ke dalam proses perencanaan strategis perusahaan dan budaya perusahaan; kedua, pemahaman bahwa semua tindakan perusahaan terkait langsung dengan operasi inti perusahaan tersebut; ketiga, keyakinan bahwa perusahaan berusaha untuk memahami dan respons terhadap kebutuhan pemangku kepentingan; keempat, perusahaan beralih dari perspektif jangka pendek ke perencanaan jangka menengah dan panjang dan proses manajemen sumber daya perusahaan di dalamnya termasuk pemangku kepentingan utama dan; kelima perusahaan bermaksud mengoptimalkan nilai yang diciptakan (Agudelo et al., 2019).

Di Indonesia, kewajiban perusahaan untuk melaksanakan CSR secara umum diatur dalam beberapa ketentuan, antara lain Undang-Undang No. 40 Tahun 2007 pasal 66 ayat (2) bagian c dan pasal 74 ayat 1 dan 2 tentang Perseroan Terbatas, Undang Undang No. 25 Tahun 2007 pasal 15(b) dan pasal 16(d) tentang Penanaman Modal dan Peraturan Pemerintah No. 47 Tahun 2012 Tentang Tanggung Jawab Sosial dan Lingkungan Perseroan Terbatas (Hanggarwati dan Mutmainah, 2013). Berdasarkan pasal dan ayat dalam undang-undang PT dan peraturan pemerintah tersebut, hanya perseroan di bidang dan/atau berkaitan dengan sumber daya alam sajalah yang wajib melaksanakan Tanggung Jawab Sosial dan Lingkungan. Perusahaan di bidang lain tidak diwajibkan sehingga hanya bersifat suka rela.

Terkait isu CSR, Cahan et al. (2017) menganalisis enam dari tujuh isu kualitatif kinerja CSR yang disajikan Kinder, Lydenberg, Domini STATS database of MSCI ESG Research, Inc $(K L D)$. Keenam isu tersebut adalah isu tentang masyarakat, keanekaragaman, hubungan ketenagakerjaan, lingkungan, hak asasi manusia dan produk. Isu $C G$ tidak dianalisis tapi dijadikan sebagai variabel pengendali. Sementara Hoq et al., (2010), Saleh et al. (2010), Damayanti dan Muid (2011), Hanggarwati dan Mutmainah (2013) dan Eriandani (2014) menganalisis CSR dalam empat isu, yaitu hubungan ketenagakerjaan, keterlibatan masyarakat, produk dan lingkungan.

\section{Corporate Governance (CG)}

Disamping unsur sosial dan lingkungan, CG juga merupakan obyek kegiatan investasi etis. Hal ini mendasarkan pada definisi investasi etis sebagaimana dijelaskan Sandberg et al. (2009) dan Gillet dan Salaber-Ayton (2017). Sandberg et al. (2009: 519) menyatakan: "During the last couple of decades, a new kind of investing has emergedmost often called ethical or socially responsible investing - which seeks to integrate certain kinds of non-financial concerns - variously called ethical, social, environmental or corporate governance criteria".

Sementara Gillet dan Salaber-Ayton (2017: 1) menyatakan "Ethical investments include both socially responsible investments (following Environmental, Social and Governance criteria) and faith-based investments (following religious principles). Aspek CG bersama aspek sosial dan lingkungan menjadi domain dalam pembahasan investasi etis (Nofsinger et al., 2016; Gillet dan Salaber-Ayton, 2017).

Pada tahun 1980-an ketiga istilah, yaitu environmental, social and governance (ESG) menjadi istilah jenis investasi tersendiri yang dikenal dengan "ESG Investing". ESG Investing merupakan istilah umum yang mencakup setiap strategi investasi yang menekankan struktur tata kelola perusahaan atau dampak lingkungan atau sosial dari produk atau praktik perusahaan (Schanzenbach dan Sitkoff, 2020). ESG Investing merupakan kegiatan investasi yang mendasarkan pertimbangan lingkungan, sosial dan corporate governance (Grim dan Berkowitz, 2018). 
Motif awal ESG Investing adalah moral dan etika yang mendasarkan dampak pada pihak ketiga dibandingkan motif keuntungan. Jenis investasi ini bermula dari gerakan investasi berbasis tanggung jawab sosial (The Socially Responsible Investing/SRI) yang muncul di tahun 1980-an sebagai bagian kampanye divestasi saham perusahaan pendukung rejim aperheid Afrika Selatan. Di akhir 1990-an dan awal 2000an istilah SRI berganti nama menjadi $E S G$ setelah mempertimbangkan unsur $G$ (corporate governance) (Schanzenbach dan Sitkoff, 2020). Keberadaan ESG Investing menunjukan bahwa investor memandang penting unsur lingkungan, sosial dan corporate governance sebagai satu kesatuan yang harus diterapkan manajemen perusahaan.

$C G$ memiliki hubungan dengan etika. Ini terlihat dari konsep prinsip-prinsip $C G$ yang dijelaskan oleh beberapa lembaga. OECD, misalnya, menjelaskan lima prinsip $C G$, yaitu transparancy, accountability, responsibility, independency dan fairness. Prinsip-prinsip tersebut merupakan sifat etis dari $C G$, bahkan dianggap sebagai nilai etika utama (cardinal ethical values) (Nainawat dan Meena, 2013). Nilai-nilai tersebut nantinya harus meresap ke semua aspek tata kelola dan diwujudkan dalam semua tindakan dan keputusan dewan. Berbagai aspek tata kelola seperti kekomplekan dewan, pelaporan, pengungkapan dan manajemen risiko, dipandang sebagai instrumen dalam mewujudkan nilai-nilai etika utama $C G$ tersebut (Nainawat dan Meena, 2013).

Secara umum ada dua definisi $C G$ : definisi secara sempit dan secara luas (Hasan, 2009). Secara sempit, CG merupakan suatu sistem pertanggungjawaban secara formal dari manajemen senior kepada pemegang saham. Konsep $C G$ ini terbatas pada hubungan antara perusahaan dan pemegang sahamnya (Feizizadeh, 2012). Penyusunan $C G$ hanya untuk memastikan bahwa kepentingan pemegang saham terlindungi. Pengertian ini didukung oleh Shleifer dan Vishny (1997) dan sejumlah dokumen kebijakan dan pedoman praktis CG seperti the Cadbury Report (1992), the Combined Code (1998; 2003; 2006), the Greenbury Report (1992), Sarbanes Oxley legislation (Brennan dan Solomon, 2008).

Adapun dalam arti luas, pengertian $C G$ mencakup seluruh jaringan hubungan baik formal ataupun informal yang melibatkan sektor perusahaan dan konsekuensinya terhadap masyarakat secara umum (Hasan, 2009). $C G$ merupakan jaringan hubungan bukan hanya antara perusahaan dan pemegang saham tetapi juga antara perusahaan dan pemangku kepentingan lainnya seperti karyawan, pelanggan, pemasok dan kreditur (Feizizadeh, 2012). Dalam arti luas, $C G$ merupakan mekanisme yang ditujukan untuk memenuhi pemangku kepentingan secara keseluruhan.

\section{Religius}

Unsur religius menjadi salah satu obyek investasi etis mendasarkan pada definisi investasi etis seperti dijelaskan Dunfee (2003), Gillet dan Salaber-Ayton (2017) dan Humphrey dan Lee (2011). Dunfee (2003: 248) menjelaskan "The broadest definition of social investing would be any investment strategy based upon identifiable non-financial criteria incorporating a social or religious dimension". Sementara Gillet dan SalaberAyton (2017: 1) menyatakan "Ethical investments include both socially responsible investments (following evironmental, social and governance criteria) and faith-based investments (following religious principles)". Adapun Humphrey dan Lee (2011:2) menyatakan "socially responsible investment (SRI) is an investment approach that includes investors' ethical, religious, social or other normative preferences into the investment decision"

Dalam pengujian aspek religius sebagai dasar pertimbangan investasi etis, investor diasumsikan akan memilih portofolio saham yang masuk dalam indek etis 
berbasis keyakinan. Indeks etis berbasis keyakinan merupakan indek saham yang pembentukannya mendasarkan prinsip-prinsip ajaran agama. Oleh karena itu saham yang masuk dalam indek tersebut dianggap telah memiliki kesesuaian dengan prinsipprinsip ajaran agama (religius).

Istilah "indek saham berbasis etis keyakinan (faith-based ethical indexes)" secara umum merujuk pada istilah "faith-based investment" (Liston dan Soydemir, 2010; Forte dan Miglietta, 2011; Gillet dan Salaber-Ayton, 2017;), "faith-based funds" (Mazouz et al., 2016), "faith based investing" (Golombik et al., 2011; Al-Awadhi, 2017) dan "faith-based ethical investing" (Hassan dan Girard, 2010). Indek saham berbasis etis keyakinan merupakan indek saham yang pembentukannya mendasarkan prinsip-prinsip ajaran agama (keyakinan). Contoh indek ini antara lain FTSE KLD Catholic Values 400 Index (CV400) yang mendasarkan pada pedoman SRI yang diterbitkan oleh the United States Conference of Catholic Bishops (USCCB), the Dow Jones Islamic Market Index (DJIM) dan the FBM EMAS Shariah Index yang mendasarkan pada prinsip-prinsip agama Islam.

Di pasar modal Indonesia, terdapat dua indek saham berbasis etis keyakinan, yaitu Indeks Saham Syariah Indonesia (ISSI) dan Jakarta Islamic Index (JII). Indek ISSI merupakan indeks komposit dimana anggotanya adalah seluruh saham syariah yang tercatat di BEI dan masuk ke dalam Daftar Efek Syariah (DES) yang diterbitkan OJK. Jadi BEI tidak melakukan seleksi saham syariah yang masuk ke dalam ISSI. Hal ini berbeda dengan indeks JII.

Dalam indeks JII, BEI menyeleksi dan menentukan saham syariah sesuai kriteria likuiditas yang digunakan untuk menyeleksi 30 saham syariah sebagai konstituen JII. Kriteria tersebut antara lain (i) saham syariah yang masuk dalam konstituen Indeks Saham Syariah Indonesia (ISSI) telah tercatat selama 6 bulan terakhir. (ii) dipilih 60 saham berdasarkan urutan rata-rata kapitalisasi pasar tertinggi selama 1 tahun terakhir. (iii) dipilih 30 saham berdasarkan rata-rata nilai transaksi harian di pasar regular tertinggi.

Pada 17 Mei 2018, BEI meluncurkan Jakarta Islamic Index 70 (JII70 Index). Sesuai namanya, Indek JII70 beranggotakan 70 saham syariah paling likuid yang tercatat di BEI. Tujuh puluh saham ini merupakan saham-saham dengan rata-rata nilai transaksi harian di pasar regular tertinggi yang dipilih dari 150 saham berdasarkan urutan ratarata kapitalisasi pasar tertinggi selama 1 tahun terakhir.

\section{Keuangan (Ekonomi)}

Michelson et al. (2004) mengartikan investasi etis sebagai integrasi nilai personal, pertimbangan sosial dan faktor ekonomi dalam keputusan investasi. Definisi tersebut menjelaskan bahwa return keuangan tetap penting meskipun bukan satusatunya faktor yang menggerakan investasi. Hal senada dijelaskan Cowton (2018), yang menyatakan bahwa esensi investasi etis adalah menggunakan secara bersama nilai moral dan kriteria keuangan konvensional dalam keputusan membeli, mempertahankan dan menjual saham sebagai bagian dari portofolio investasi.

Penelitian terdahulu menjadikan faktor keuangan, yang dijabarkan dalam karakteristik perusahaan, sebagai variabel pengendali. Graves dan Waddock (1994) dan Mahoney dan Roberts (2007), misalnya, menjabarkan dalam karakteristik perusahaan: profitabilitas (ROA dan ROE), ukuran perusahaan, tingkat utang dan industri. Harjoto et al. (2015) menjabarkan dalam karaketeristik perusahaan: kinerja, likuiditas, resiko dan ukuran perusahaan. Cahan et al. (2017) menjabarkan dalam karaketeristik perusahaan: ukuran perusahaan, reputasi, kinerja keuangan dan saham, likuiditas, resiko dan variabel fundamental (EP, DP, BP, SaleChg). 


\section{METODOLOGI PENELITIAN \\ Pendekatan (Strategi) Investasi Etis}

Secara umum, investor menggunakan tiga strategi dalam kegiatan investasi etis, yaitu skrining (screening), aktivis pemegang saham (shareholder activism ladvocacy) dan investasi (pengembangan) masyarakat (community (development) investing) (Schueth, 2003; Sandberg et al., 2009; Golombick et al., 2011; von Wallis dan Klein, 2015). Di Eropa di samping menggunakan shareholder activism juga dikenal menggunakan proxy voting. Strategi shareholder activism lebih menekankan dialog privat antara investor dan perusahaan sementara strategi proxy voting lebih menekankan konfrontasi (Louche dan Lydenberg, 2006).

Sandberg et al. (2009) mengutip laporan Sosial Investment Forum (SIF) 2003 bahwa seperlima aset investasi etis di Amerika Serikat diperoleh melalui strategi aktivis pemegang saham, sementara strategi pengembangan masyarakat kurang begitu dikenal (less common). McCahery, Sautner dan Starks (2015) mengadakan survey tentang mekanisme (strategi) investor institusi dalam mengarahkan manajemen untuk menerapkan $C G$. Dua fokus mekanisme yang ditanyakan adalah voice (shareholder activism) dan exit (screening). Survey menemukan responden (investor etis institusi) lebih sering menggunakan mekanisme voice, sementara lebih dari $40 \%$ responden percaya bahwa mekanisme exit dapat mendisiplinkan manajemen.

\section{HASIL PENELITIAN \\ Skrining (screening)}

Skrining merupakan praktik memasukan perusahaan dalam atau mengeluarkan perusahaan (sekuritas publik) dari portofolio investasi atau reksadana berdasarkan kriteria sosial dan/atau lingkungan (Schueth, 2003; Barnea, Heinkel dan Kraus, 2005; Michelson et al., 2004). Renneboog et al., (2007a, b) mengutip lembaga Social Investment Forum (SIF) tahun 2003 yang melaporakan 64\% dari reksadana etis di Amerika Serikat menggunakan lebih dari lima jenis skrining, sementara $18 \%$ nya hanya menggunakan satu jenis skrining.

Secara umum, ada dua jenis strategi investasi etis skrining, yaitu strategi negatif dan strategi positif.

\section{a. Strategi Skrining Negatif}

Skrining negatif dikenal juga dengan istilah exclusionary screening (Barnea et al., 2005), investor boycott (Hylton, 1992; Cahan et al., 2017), atau avoidance strategies (Sandberg et al., 2009). Skrining negatif merupakan strategi pertama dan paling sederhana (Hylton, 1992) serta dianggap sebagai jantungnya strategi investasi etis (Cowton, 2018). Skrining negatif merupakan pendekatan (strategi) yang ditandai oleh pemisahan atau penghindaran terhadap perilaku perusahaan yang dipertanyakan secara etis (Hylton, 1992; Cahan et al., 2017). Dalam skrining ini, perusahaan dengan karakteristik khusus dikeluarkan dari pertimbangan (von Wallis dan Klein, 2015). Karakteristik ini terkait cara menjalankan bisnis atau sifat dari produk yang dihasilkan (Cowton, 1994).

Skrining negatif biasanya pasif dan absolut, dalam arti tidak ada perkecualian untuk perusahaan tertentu. Meskipun perusahaan memiliki nilai kualitas tertentu dan menghasilkan keuntungan tetap tidak dimasukan dalam portofolio (Magnússon dan Dyremyhr, 2011). Topik skrining negatif beragam meliputi sin stocks (gambling, alcohol, tobacco), military contracting, nuclear power, a company's environmental record, product quality, attitude toward consumers, corporate citizenship, employee 
relations, cultural diversity, mention political donations dan oppressive government regimes (von Wallis dan Klein, 2015). Skrining negatif juga dapat didasarkan pada ideologi tradisional keyakinan agama, seperti mengeluarkan dari portofolio investasi, perusahaan produsen makanan berbahan daging babi, perusahaan keuangan yang memberikan return bunga atau perusahaan asuransi yang mengasuransikan pasangan berlum menikah (Renneboog et al., 2007a, b).

Terkait hubungan segmen investor dan penggunaan jenis skrining, Derwall, Koedijk dan Ter Horst (2011) berargumen bahwa skrining negatif dipraktikan oleh segmen investor berbasis nilai (values-driven investors). Mereka menggunakan strategi negatif untuk menghindari saham-saham yang kontroversial secara etis. Investor berbasis nilai adalah investor yang mendasarkan keputusan investasinya pada nilai personal dan sosial dan rela menerima kerugian finansial guna mendapatkan utilitas nonkeuangan (Cahan et al., 2017).

\section{b. Strategi Skrining Positif}

Istilah lain skrining positif antara lain inclusionary screening (Barnea et al., 2005), supportive strategies, incentive investment, guideline portfolio investing (Sandberg et al., 2009). Skrining positif merupakan pendekatan investasi etis dengan memilih perusahaan berdasarkan kontribusi positifnya terhadap masyarakat (Barnea et al., 2005) atau berdasarkan keterlibatannya secara aktif pada isu-isu beorientasi stakeholder tertentu (Areal, Cortez dan Silva, 2010). Investor yang menerapkan strategi ini akan berinvestasi hanya di perusahaan yang memiliki kriteria tertentu (von Wallis dan Klein, 2015) seperti kriteria sosial, lingkungan dan etika (SEE) (Renneboog et al., 2007a, b). Paling umum fokus pada kriteria corporate governance, hubungan perburuhan, lingkungan, keberlanjutan investasi, dan stimulasi keberagaman budaya. Skrining Positif juga sering digunakan untuk menseleksi perusahaan yang memiliki track record baik di bidang penggunanaan energi kebaruan dan keterlibatan masyarakat.

Terkait hubungan segmen investor dan penggunaan jenis skrining, Derwall et al. (2011) berargumen bahwa strategi positif dipraktikan oleh segmen investor berbasis laba (pofit-driven investors). Mereka menggunakan skrining ini dengan mengidentifikasi perusahaan berkinerja CSR tinggi yang dapat mempengaruhi laba perusahaan (Cahan et al., 2017).

Skrining positif memiliki lingkup yang lebih luas dibandingkan skrining negatif. Hal ini karena skrining positif dapat diterapkan terhadap setiap perusahaan. Skrining ini proaktif dalam memberi penghargaan dan semangat terhadap perilaku baik perusahaan.

Meskipun demikian, praktik penerapan skrining positif lebih memakan biaya dan sulit dilakukan (Cahan et al., 2017). Sulit menemukan perusahaan yang memenuhi semua kriteria skrining dalam strategi skrining positif (Magnússon dan Dyremyhr, 2011). Penerapan skrining positif mensyaratkan investor mengidentifikasi kriteria seleksi, menentukan pengukuran yang sesuai kriteria dan menetapkan benchmark untuk mengidentifikasi praktik terbaik (best practice) (Cahan et al., 2017).

\section{c. Strategi Skrining Lainnya}

Strategi skrining lainnya, disamping skrining negatif dan skrining positif, antara lain strategi a best-in-class (best-in-industry) (Michelson et al., 2004), skrining generasi ketiga (sustainability/triple bottom line) dan skrining generasi keempat (Renneboog, ter Horst dan Zhang, 2007; von Wallis dan Klein, 2015). Skrining a best-in-class berusaha membandingkan dan meranking (kinerja sosial, lingkungan dan etika) satu perusahaan dengan perusahaan lainnya dalam sektor industri yang sama (Michelson et al., 2004). Hanya perusahaan dengan kinerja sosial, lingkungan dan etika yang melewati ambang 
batas ketentuan yang akan dimasukan dalam portofolio investasi (Renneboog et al., 2007a, b).

Sementara skrining ketiga dan keempat merupakan kelanjutan dari skrining negatif (skrining generasi pertama) dan skrining positif (skrining generasi kedua) (von Wallis dan Klein, 2015). Skrining generasi ketiga merupakan strategi pemilihan perusahaan berdasarkan kriteria ekonomi, lingkungan, dan sosial baik dengan mengintegrasikan skrining negatif dan skrining positif (Renneboog et al., 2007). Strategi ini mencoba mengintegrasikan, baik integrasi kriteria (ekonomi, lingkungan dan sosial) ataupun integrasi skrining (negatif dan positif). Strategi generasi ketiga dikenal juga dengan istilah "sustainability" atau "triple bottom line" karena fokus pada People, Planet dan Profit. Adapun skrining generasi keempat merupakan strategi pemilihan perusahaan dengan mengkombinasikan strategi generasi ketiga dan strategi aktivis pemegang saham (shareholder activism) dan komitmen (Renneboog et al., 2007a, b).

\section{Aktivisme Pemegang Saham (Shareholder Activism)}

Aktivisme pemegang saham memiliki sejarah panjang terhadap tumbuhnya kegiatan investasi etis, bahkan strategi ini semakin meluas dan bernuansa dalam beberapa tahun terakhir. Strategi ini cenderung dilakukan oleh investor institusi dibandingkan individual (Michelson et al., 2004). Kebanyakan difokuskan pada isu-isu besar seperti masalah apartheid (di masa lalu), proses operasi perusahaan pertambangan di negara berkembang dan pembayaran eksekutif (Cowton, 2018).

Aktivisme pemegang saham merupakan teknik (strategi) investasi etis berupa penggunaan hak suara, melalui kepemilikan saham biasa, untuk menegaskan dan mencapai tujuan politik, keuangan dan tujuan lainnya (Sparkes, 2001). Dalam kontek investasi etis, investor menggunakan hak suaranya untuk mendukung pengembangan etis suatu perusahaan (von Wallis dan Klein, 2015). Mereka berinvestasi pada perusahaan yang memiliki permasalahan secara etis dan berharap merubahnya dengan meyakinkan bahwa perusahaan punya tanggung jawab etis terhadap masyarakat dimana perusahaan tersebut beroperasi. Berbeda dengan strategi skrining, dalam strategi aktivisme pemegang saham, investor percaya bahwa cara terbaik untuk mengefektifkan perubahan perilaku perusahaan adalah dengan memelihara hubungan dengan perusahaan tersebut (Hylton, 1992).

Di Amerika Serikat, terdapat kelompok yang memanfaatkan strategi aktivisme pemegang saham untuk memaksa perusahaan yang dianggap berkinerja rendah berubah ke arah kinerja yang lebih tinggi. Kelompok tersebut adalah investor yang murni memiliki tujuan keuangan. Ada juga kelompok lain, yaitu lembaga masyarakat (NGO). Lembaga ini menggunakan strategi aktivisme pemegang saham untuk mengkritisi kegiatan perusahaan di bidang tertentu seperti lingkungan, hak-hak binatang atau kesejahteraan masyarakat lokal (Sparkes, 2001).

Di samping penggunaan hak suara (voting rights), investor juga sering menggunakan media dialog secara diam-diam (private behind - the - scenes dialogue). Melalui media ini, isu yang muncul dibahas secara bersama antara investor (pemegang saham) dengan manajemen tanpa perlu respon publik sehingga pembahasannya lebih konstruktif dan produktif (Cowton, 2018). Investor sering bekerja sama mengarahkan manajemen pada kasus yang diyakini akan meningkatkan kinerja keuangan dan meningkatkan kesejahteraan semua pemangku kepentingan perusahaan (pelanggan, karyawan, vendor, masyarakat, lingkungan dan pemegang saham) (Schueth, 2003).

\section{Investasi Pengembangan Masyarakat (Community Development Investing)}


Investasi Pengembangan Masyarakat merupakan strategi investasi etis dengan memberikan sejumlah dana (modal) kepada masyarakat berpenghasilan rendah dan beresiko yang sulit mengakses modal melalu jaringan konvensional (Schueth, 2003). Lembaga the Social Investment Forums (SIF) Amerika Serikat sangat mendorong strategi ini dengan meluncurkan kampanye "a One Percent for Community" untuk menyemangati semua pengelola dana baik, baik etis ataupun konvensional, agar berinvestasi setidaknya satu persen dari aset mereka di lembaga pengembangan masyarakat (Louche dan Lydenberg, 2006). Investasi disalurkan melalui lembaga masyarakat yang misinya fokus pada pengembangan usaha masyarakat lemah (Schueth, 2003), seperti bantuan amal, keterlibatan kemitraan publik-swasta, atau program voluntari (von Wallis dan Klein, 2015).

Meskipun kebanyakan literatur memasukan strategi investasi pengembangan masyarakat sebagai bagian strategi investasi etis (Sandberg et al., 2008), tetapi Sparkes (2001) atau masyarakat eropa secara umum (Louche dan Lydenberg, 2006) berpendapat strategi ini bukan bagian investasi etis melainkan bagian strategi Socially Directed Investments (SDI) (von Wallis dan Klein, 2015). SDI berbeda dengan dengan investasi etis $(S R I)$. SDI terjadi ketika ada pengalokasian return (subnormal return) yang ditujukan untuk pengembangan masyarakat (Sparkes, 2001). Kegiatan SDI berbasis hutang (debt-based activity), sementara kegiatan investasi etis secara umum berbasis ekuitas (equity-based activity). Esensi SDI adalah adanya kesengajaan para pemilik dana mendapatkan return di bawah pasar untuk membantu masyarakat ekonomi lemah dan ini bukan tujuan investasi etis. Strategi pengembangan investasi juga belum terlihat luas dalam literatur akademik (von Wallis dan Klein, 2015).

\section{KESIMPULAN}

Uraian di atas menjelaskan konsep, dasar (kriteria) keputusan dan pendekatan dalam kegiatan investasi etis. Mengacu Cowton (2018), Dunfee (2003), Humphrey \& Lee (2011), Renneboog et al., (2008) dan Sandberg et al. (2009), investasi etis dapat diartikan sebagai investasi yang dalam keputusan pembentukan portofolio investasi mendasarkan integrasi beberapa kriteria non-finansial antara lain etika, sosial, lingkungan, governance dan religious. Mendasarkan definisi investasi etis tersebut, ada beberapa dasar pertimbangan dalam pengambilan keputusan investasi etis, yaitu faktor etika, sosial, lingkungan, corporate governance dan religius. Adapun pendekatan yang sering dilakukan investor dalam kegiatan investasi etis antara lain portofolio skrining (skrining negatif dan positif) dan aktivisme pemegang saham (shareholder activism).

\section{DAFTAR PUSTAKA}

Al-Awadhi, A. M. (2017). Essays on Religious Beliefs and Stock Market Outcomes. A Thesis. School of Economics, Finance and Marketing College of Business RMIT University. https://researchbank.rmit.edu.au/view/rmit:162003.

Al-Awadhi, A. M. dan Dempsey, M. (2017). Social Norms and Market Outcomes: The Effects of Religious Beliefs on Stock Markets. Journal of International Financial Markets, Institutions \& Money. https://doi.org/10.1016/j.intfin.2017.05.008

Agudelo, M. A. L., Jóhannsdóttir, L. dan Davídsdóttir, B. (2019). A literature review of the history and evolution of corporate social responsibility. International Journal of Corporate Social Responsibility. 4:1, 1-23. https://doi.org/10.1186/s40991018-0039-y

Albaity, M. dan Ahmad, R. (2011). Return performance and leverage effect in Islamic and socially responsible stock indices evidence from Dow Jones (DJ) and 
Financial Times Stock Exchange (FTSE). African Journal of Business Management, 5 (16), 6927-6939. https://doi.org/10.5897/AJBM10.1063

Amory, M. (2016). Do different cultural values affect the excess return of sin stocks? Vol 2 (2016): Research in Business and Economics (MaRBLe), 2, 1-26. https://doi.org/10.26481/marble.2016.v2.260

Areal, N., Cortez, M. C. dan Silva, F. (2010). Investing in mutual funds: Does it pay to be a sinner or a saint in times of crisis? SSRN Electronic Journal, 1-22. http://ssrn.com/abstract=1676391 1 .

Barnea, A., Heinkel, R. dan Kraus, A. (2005). Green investors and corporate investment. Structural Change and Economic Dynamics, 16, 332-346. https://doi.org/10.1016/j.strueco.2004.04.002

Brennan, N. dan Solomon, J. (2008). Corporate governance, accountability and mechanisms of accountability: an overview. Accounting, Auditing and Accountability Journal, 21(7), 885-906. https://doi.org/10.1108/09513570810907401

Cahan, S. F., Chen, C. dan Chen, L. (2017). Social Norms and CSR Performance. Journal of Business Ethics, 145(3), 493-508. https://doi.org/10.1007/s10551015-2899-3

Cowton, C. J. (1994). The Development of Ethical Investment Products. In A. R. Prindl \& B. Prodhan (Eds.), Ethical Conflicts in Finance (pp. 213-232). Blackwell Publishers,.

Cowton, C. J. (2018). Socially Responsible Investing. In A. Lewis (Ed.), The Cambridge Handbook of Psychology and Economic Behaviour (pp. 285-304). Cambridge University Press. https://doi.org/10.1017/9781316676349.010.

Damayanti, M. I. dan Muid, D. (2011). Hubungan Pengungkapan Tanggung Jawab Sosial (CSR Disclosure) dengan Kepemilikan Institutional pada Perusahaan Manufaktur Go Public di Indonesia. 1-34. http://eprints.undip.ac.id/ 29845/ 1/ Jurnal_MELISA_IKA_DAMAYANTI_C2C007079.pdf

Derwall, J., Koedijk, K. dan Ter Horst, J. (2011). A tale of values-driven and profitseeking social investors. Journal of Banking and Finance, 35(8), 2137-2147. https://doi.org/10.1016/j.jbankfin.2011.01.009

Djamal, S. M. (2018). Pelaksanaan Nilai-Nilai Ajaran Islam Dalam Kehidupan Masyarakat Di Desa Garuntungan Kecamatan Kindang Kabupaten Bulukumba. Jurnal Adabiyah, 17(2), 161-179. https://doi.org/10.24252/jad.v17i1i2a5

Dunfee, T. W. (2003). Social Investing: or Backwater? Journal of Business Ethics, 43(3), 247-252.

Eriandani, R. (2014). Pengaruh Dimensi Pengungkapan Corporate Social Responsibility Terhadap Future Institutional Ownership. Jurnal Ekonomi Dan Bisnis, XVII(1), 91-110.

Feizizadeh, A. (2012). Corporate Governance: Frameworks. Indian Journal of Science and Technology, 5(9), 3353-3361. https://doi.org/10.1016/b978-0-12-3739322.00098-3

Forte, G. dan Miglietta, F. (2011). A Comparison of Socially Responsible and Islamic Equity Investments. SSRN Electronic Journal, 21(21). https://doi.org/10.2139/ssrn.1819002

GAMCO. (2016). ESG Investment Approach. Gamco Asset Management. www.gabelli.com. 
Gillet, P. dan Salaber-Ayton, J. (2017). The recent development and performance of ethical investments. In Routledge Handbook of Social and Sustainable Finance (pp. 530-546).

Golombik, J., Kumar, A. dan Parwada, J. T. (2011). Does Religion Affect Stock Markets and Institutional Investor Behavior? SSRN Electronic Journal, 1-66. https://ssrn.com/abstract $=1746564$.

Graves, S. B. dan Waddock, S. A. (1994). Institutional Owners and Corporate Social Performance. The Academy of Management Journal, 37(4), 1034-1046. https://doi.org/10.2307/256611

Grim, D.M., dan Berkowitz, D.B. (2018). ESG, SRI and Impact Investing: A Primer for Decision - Making. Vanguard Research. https://personal.vanguard.com/pdf/ ISGESG.pdf

GSIA. (2018). 2018 Global Sustainable Investment Review.

Hanggarwati, K. dan Mutmainah, S. (2013). Analisis Pengaruh Pengungkapan Corporate Social Responsibility terhadap Institutional Ownership. Diponegoro Journal of Accounting, 2(2), 1-9.

Hanum, F. (2009). Etiket-Estetika dan Komunikasi yang Efektif. http://staff.uny.ac.id/sites/default/files/pengabdian/farida-hanum-msi-dr/etiketestetika-dan-komunikasi-yang-efektif-2009.pdf

Harjoto, M., Jo, H. dan Kim, Y. (2015). Is Institutional Ownership Related to Corporate Social Responsibility? The Nonlinear Relation and Its Implication for Stock Return Volatility. Journal of Business Ethics, 1-33. https://doi.org/10.1007/s10551-015-2883-y

Hasan, Z. (2009). Corporate Governance: Western and Islamic Perspectives. International Review of Business Research Papers, 5(1), 277-293.

Hassan, M. K. dan Girard, E. (2010). Faith-Based Ethical Investing: The Case of Dow Jones Islamic Indexes. Islamic Economic Studies, 17(2). https://doi.org/10.2139/ssrn.1808853

Hong, H. dan Kacperczyk, M. (2009). The price of sin: The effects of social norms on markets. Journal of Financial Economics, 93(1), 15-36. https://doi.org/10.1016/j.jfineco.2008.09.001

Hood, M., Nofsinger, J. R. dan Varma, A. (2014). Conservation, Discrimination, and Salvation: Investors' Social Concerns in the Stock Market. Journal of Financial Services Research, 45(1), 5-37. https://doi.org/10.1007/s10693-013-0162-6

Hoq, M. Z., Saleh, M., Zubayer, M. dan Mahmud, K. T. (2010). The Effect of CSR Disclosure on Institutional Ownership. Pak. J. Commer. Soc. Sci., 4(1), 22-39.

Humphrey, J. E. dan Lee, D. D. (2011). Australian socially responsible funds performance, risk and screening intensity. Journal of Business Ethics, 102(4), 519-535.

Hylton, M. O. (1992). "Socially Responsible" Investing: Doing Good Versus Doing Well in an Inefficient Market. The American University Law Review, 42(1), 152.

Inderst, G. dan Stewart, F. (2018). Incorporating Enviromental, Social and Governance (ESG) Factors into Fixed Income Investment. World Bank Group publication. www.worldbank.org.

Kim, I. dan Venkatachalam, M. (2011). Are sin stocks paying the price for their accounting sins? Journal of Accounting, Auditing \& Finance, 26(2), 415-442. https://doi.org/10.1177/0148558X11401222 
Leventis, S., Hasan, I. dan Dedoulis, E. (2013). The Cost of Sin: The effect of social norms on audit pricing. International Review of Financial Analysis, 29, 152165. https://doi.org/10.1016/j.irfa.2013.03.006

Liston, D. P. (2016). Sin stock returns and investor sentiment. Quarterly Review of Economics and Finance, 59, 63-70. https://doi.org/10.1016/j.qref.2015.08.004

Liston, D. P. dan Soydemir, G. (2010). Faith-based and sin portfolios: An empirical inquiry into norm-neglect vs norm-conforming investor behavior. Managerial Finance, 36(10), 876-885. https://doi.org/10.1108/03074351011070242

Louche, C. dan Lydenberg, S. (2006). Socially Responsible Investment: Differences between Europe and United States. In Vlerick Leuven Gent Management School Working Paper Series 2006-22,.

Magnússon, M. B. dan Dyremyhr, T. E. (2011). Ethical Investments (Issue June). Thesis. Department of Finance, Copenhagen Business School.

Mahoney, L. dan Roberts, R. W. (2007). Corporate social performance, financial performance and institutional ownership in Canadian firms. Accounting Forum, 31(3), 233-253. https://doi.org/10.1016/j.accfor.2007.05.001

M Purba, D Simanjutak, Y Malau, W Sholihat, E Ahmadi. 2021. The Effect Of Digital Marketing And E-Commerce On Financial Performance And Business SustainaBility Of Msmes During Covid-19 Pandemic In Indonesia. International Journal Of Data And Network Science. Jilid 5. Terbitan 3. Halaman 275-282

Mazouz, K., Mohamed, A. dan Saadouni, B. (2016). Price Reaction of Ethically Screened Stocks: A Study of the Dow Jones Islamic Market World Index. Journal of Business Ethics, 154(3), 683-699. https://doi.org/10.1007/s10551016-3389-y

Mccahery, J. A., Sautner, Z. dan Starks, L. T. (2016). Behind the Scenes: The Corporate Governance Preferences of Institutional Investors. The Journal of Finance, Volume 71, Issue 6, pp. 2905-2932. https://doi.org/10.1111/jofi.12393

Michelson, G., Wailes, N., van der Laan, S. dan Frost, G. (2004). Ethical Investment Processes and Outcomes. Journal of Business Ethics, 52(52), 1-10. https://doi.org/10.1023/B:BUSI.0000033103.12560.be

Nainawat, R dan Meena, R. (2013). Corporate Governance and Business Ethics. Global Journal of Management and Business Studies. Global Journal of Management and Business Studies. Vol. 3, No. 10, pp. 1085-1090.

Nofsinger, J. . R., Chair, W. H. S., Sulaeman, J. dan Varma, A. (2016). Institutional Investors and Socially Responsible Investments: It Just Makes (Economic) Sense. 1-62. Working Peper. University of Alaska Fairbanks.

Ortas, E. dan Moneva, J. M. (2010). Conditional volatility in sustainable and traditional stock exchange indexes: analysis of the Spanish market. GCG: Revista de Globalización, Competitividad \& Gobernabilidad, 4(2), 104-129.

Pena, J. dan Cortez, M. C. (2017). Social screening and mutual fund performance: international evidence. 1-67. https://efmaefm.org/OEFMAMEETINGS/EFMA ANNUAL MEETINGS/2017-Athens/papers/EFMA2017_0206_fullpaper.pdf

Peraturan Pemerintah Republik Indonesia. Nomor 47 Tahun 2012 Tentang Tanggung Jawab Sosial dan Lingkungan Perseroan Terbatas. (n.d.).

Rafik, A. dan Lantara, I. W. . N. (2016). An empirical study on index changes on the Indonesia Stock Exchange. Afro-Asian J. Finance and Accounting, 6(2), 87116. https://doi.org/10.1504/AAJFA.2016.077322 
REBECO. (n.d.). ESG Definition. Rebeco Asset Management. https://www.robeco.com/en/key-strengths/sustainability-investing/glossary/esgdefinition.html

Reich, M. C., Wolff, R., Zaring, O., Zetterberg, L., dan Åhman, M. (2001). Ethical Investments-Towards a Sound Theory and Screening Methodology (B 1425, Issue October). Swedish Environmental Research Institute.

Renneboog, L. ., Ter Horst, J., dan Zhang, C. (2008). The price of ethics and stakeholder governance: The performance of socially responsible mutual funds. Journal of Corporate Finance, 14(3), 302-322. https://doi.org/10.1016/j.jcorpfin.2008.03.009

Renneboog, L., ter Horst, J., dan Zhang, C. (2007a). Socially Responsible Investments: Methodology, Risk Exposure and Performance. In ECGI W0rking Peper Series in Finance (175/2007; 2007-013, Issue 175). https://doi.org/10.2139/ssrn.985267

Renneboog, L., ter Horst, J. dan Zhang, C. (2007b). The Price of Ethics: Evidence from Socially Responsible Mutual Funds. In TILEC Discussion Paper (Vol. 012).

Republik Indonesia. Undang-Undang No 40 Tahun 2007 tentang Perseroan Terbatas.

Republik Indonesia. Undang Undang Nomor 25 Tahun 2007 tentang Penanaman Modal. (n.d.).

Revelli, C., dan Viviani, J.-L. (2013). The Link Between SRI and Financial Performance: Effects and Moderators. Management International, 17(2), 105122. https://doi.org/10.7202/1015403ar

Richey, G. (2017). Fewer reasons to sin: a five-factor investigation of vice stock returns. Managerial Finance, 43(9), 1016-1033. https://doi.org/10.1108/MF-09-20160268

Rockness, J. dan Williams, P. F. (1988). A descriptive study of social responsibility mutual funds. Accounting, Organizations and Society, 13(4), 397-411. https://doi.org/10.1016/0361-3682(88)90013-X

Salaber, J. (2013). Religion and returns in Europe. European Journal of Political Economy, 32, 149-160. https://doi.org/10.1016/j.ejpoleco.2013.07.002

Saleh, M., Zulkifli, N. dan Muhamad, R. (2010). Corporate social responsibility disclosure and its relation on institutional ownership: Evidence from public listed companies in Malaysia. Managerial Auditing Journal, 25(6), 591-613. https://doi.org/10.1108/02686901011054881

Sandberg, J., Juravle, C., Hedesström, T. M. dan Hamilton, I. . (2009). The heterogeneity of socially responsible investment. Journal of Business Ethics, 87(4), 519-533. https://doi.org/10.1007/s10551-008-9956-0

Schanzenbach, M.M dan Sitkoff, R.H. (2020). ESG Investing: Theory, Evidence, and Fiduciary Principles. Journal of Financial Planning, https://ssrn.com/ abstract $=3684979$

Schueth, S. (2003). Socially responsible investing in the United States. Journal of Business Ethics, 43(3), 189-194. https://doi.org/10.1023/A:102298182

Shleifer, A. dan Vishny, R. W. (1997). A Survey of Corporate Governance. The Journal of Finance, LII(2), 737-783. https://doi.org/10.1111/j.15406261.1997.tb04820.x

Sparkes, R. (2001). Ethical investment: whose ethics, which investment? Business Ethics: A European Review, 10(3), 194-205. https://doi.org/10.1111/14678608.00233 
Trinks, P. J. dan Scholtens, B. (2017). The Opportunity Cost of Negative Screening in Socially Responsible Investing. Journal of Business Ethics, 140(2), 193-208. https://doi.org/10.1007/s10551-015-2684-3

Tseng, M. L., Tan, P. A., Jeng, S. Y., Lin, C. W. R., Negash, Y. T. dan Darsono, S. N. A. C. (2019). Sustainable investment: Interrelated among corporate governance, economic performance and market risks using investor preference approach. Sustainability (Switzerland), 11(7), 1-15. https://doi.org/10.3390/su11072108

von Wallis, M. dan Klein, C. (2015). Ethical requirement and financial interest: a literature review on socially responsible investing. Business Research, 8(1), 6198. https://doi.org/10.1007/s40685-014-0015-7 